\title{
Chorioamnionitis and neonatal outcome: early vs late preterm infants
}

\author{
Lidia Decembrino*, Margherita Pozzi, Rossana Falcone, Mauro Stronati \\ From XX National Congress of the Italian Society of Neonatology \\ Rome, Italy. 9-11 October 2014
}

Chorioamnionitis (CA) describes an intrauterine status of inflammation and/or infection of placental membranes, refering to both histological and clinical CA [1]. It is considered the major risk of spontaneous preterm delivery, especially at earlier gestational age. The intrauterine exposure to infection/inflammation leads to the fetal inflammatory syndrome (FIRS) that together with CA is responsible for multiple organ injury, neonatal morbidity and mortality [2]. Strong evidences support that neonates exposed to CA are sicker at birth, have a higher rates of early-onset sepsis, respiratory distress syndrome (RDS), bronchopulmonary dysplasia (BPD), intraventricular hemorrhage (IVH), retinopathy of prematurity (ROP), patent ductus arteriousus (PDA) and surgical necrotizing enterocolitis (NEC) as compared with unexposed neonates [3-6]. Neonates with $\leq 28$ weeks of gestational age (GA) have a significantly higher mortality than neonates with a longer gestation period [7]. Recently Pappas et al reported an increased odds of cognitive impairment and death/neurodevelopmental impairment in extremely low birth weight (ELBW) exposed to CA [8]. In infants born at 36 weeks or later in gestation CA has been indentified as an independent risk factor of CP [9]. Lee et al highlighted that acute histologic CA is a risk factor for adverse neonatal outcome in late preterm birth after preterm premature rupture of membranes (PPROM) [10]. Neverthless, the effects of CA on the neonatal outcome remain under debate, because gestation-independent effects of CA on neonatal outcomes are difficult to assess. Thus in some studies at adjusted analyses for GA, the adverse impact of CA on neonatal outcome is not confirmed [11]. Additionally in many study groups discrimination between ELBW and late preterm infants is not considered. In the future, sufficiently powered cohort

\footnotetext{
* Correspondence: lidiadec@alice.it

Neonatal Intensive Care Unit, Fondazione IRCCS Policlinico San Matteo, Pavia, Italy
} able to provide useful informations regarding the different outcome between extremely and late preterms infants. An dequate antenatal screening and treatment for CA will improve the prognosis for infants at risk of multiple organ disease as a result of exposure to infection/inflammation before birth [12-14].

Published: 9 October 2014

References

. Hagberg H, Wennerholm UB, Savman K: Sequelae of chorioamnionitis. Curr Opin Infect Dis 2002, 15:301-306.

2. Gotsch F, Romero R, Kusanovic JP, Mazaki-Tovi S, Pineles BL, Erez O, Espinoza J, Hassan SS: The Fetal Inflammatory Response Syndrome. Clinical Obstetrics and Gynecol 2007, 50(3):652-683.

3. Galinsky R, Polglase GR, Hooper SB, Back MJ, Moss TJ: The Consequences of Chorioamnionitis: Preterm Birth and Effects on Development. J Pregnancy 2013, 2013(2013):412831.

4. Bersani I, Thomas W, Speer CP: Chorioamnionitis - the good or the evil for neonatal outcome? The Journal of Maternal-Fetal and Neonatal Medicine 2012, 25(Suppl 1):12-16

. Seliga-Siwecka JP, Kornacka MK: Neonatal outcome of preterm infants born to mothers with abnormal genital tract colonisation and chorioamnionitis: A cohort study. Early Human Development 2013, 89:271-275.

6. Been JV, Lievense S, Zimmermann LJ, Kramer BW, Wolf TG: Chorioamnionitis as a risk factor for Necrotizing Enterocolitis: A Systematic Review and Meta-Analysis. J Pediatr 2013, 162:236-42.

Stimac M, Vukelic V, Perusko Matasic NP, Kos M, Babic D: Effect of chorioamnionitis on mortality, early onset neonatal sepsis and bronchopulmonary dysplasia in preterm neonates with birth weight of $\leq 1,500$ grams. Coll. Antropol 2014, 38(1):167-171.

8. Pappas A, Kendrick DE, Shankaran S, Stoll BJ, Bell EF, Laptook AR, Walsh MC, Das A, Hale EC, Newman NS, Higgins RD, Eunice Kennedy Shriver Nationa Institute of Child Health and Human Development Neonatal Research Xeow-Gestational-Age Neonates. JAMA Pediatr 2014 168(2):137-147.

9. Wu YW, Escobar GJ, Grether JK: Chorioamnionitis and cerebral palsy in term and near-term infants. JAMA 2003, 290:2677-2684.

10. Lee SM, Park JW, Kim BJ, Park CW, Park JS, Jun JK, Yoon BH: Acute Histologic Chorioamnionitis Is a Risk Factor for Adverse Neonatal Outcome in Late Preterm Birth after Preterm Premature Rupture of Membranes. PloS One 2013, 8(12):e79941. 
11. Mitra S, Aune D, Speer CP, Saugstad OD: Chorioamnionitis as a Risk Factor for Retinopathy of Prematurity: A Systematic Review and Meta-Analysis. Neonatology 2014, 105:189-199.

12. Popowski T, Goffinet F, Maillard F, Schmitz T, Leroy S, Kayem G: Maternal markers for detecting early-onset neonatal infection and chorioamnionitis in cases of premature rupture of membranes at or after 34 weeks of gestation: a two-center prospective Study. BMC Pregnancy and Childbirth 2011, 11:26.

13. Tita ATN, Andrews WW: Diagnosis and Management of Clinical Chorioamnionitis. Clin Perinatol 2010, 37(2):339-354.

14. Been JV, Degraeuwe PL, Kramer BW, Zimmermann L: Antenatal steroids and neonatal outcome after chorioamnionitis: a meta-analysis. BJOG 2011, 118:113-122

doi:10.1186/1824-7288-40-S2-A22

Cite this article as: Decembrino et al: Chorioamnionitis and neonatal outcome: early vs late preterm infants. Italian Journal of Pediatrics 2014 40(Suppl 2):A22.

\section{Submit your next manuscript to BioMed Central} and take full advantage of:

- Convenient online submission

- Thorough peer review

- No space constraints or color figure charges

- Immediate publication on acceptance

- Inclusion in PubMed, CAS, Scopus and Google Scholar

- Research which is freely available for redistribution

Submit your manuscript at www.biomedcentral.com/submit
C Biomed Central 